\title{
Prognostic significance of HER3 and HER4 protein expression in colorectal adenocarcinomas
}

\author{
Panteleimon Kountourakis*1,2, Kitty Pavlakis ${ }^{3}$, Amanda Psyrri1,2, \\ Dimitra Rontogianni ${ }^{4}$, Nikolaos Xiros ${ }^{1}$, Efstratios Patsouris ${ }^{3}$, \\ Dimitrios Pectasides ${ }^{1}$ and Theofanis Economopoulos ${ }^{1}$
}

\begin{abstract}
Address: ${ }^{1}$ Second Department of Internal Medicine-Propaedeutic, Athens University Medical School, Attikon university Hospital, Athens, Greece, ${ }^{2}$ Yale Cancer Center, New Haven, CT, USA, ${ }^{3}$ Pathology Department, Athens University Medical School, Greece and ${ }^{4}$ Pathology Department, Evangelismos Hospital, Athens-Hellas, Greece

Email: Panteleimon Kountourakis* - panteleimon.kountourakis@yale.edu; Kitty Pavlakis - epavlaki@med.uoa.gr; Amanda Psyrri - diamando.psyrri@yale.edu; Dimitra Rontogianni - dgian@otenet.gr; Nikolaos Xiros - nxiros@otenet.gr; Efstratios Patsouris - epatsour@med.uoa.gr; Dimitrios Pectasides - pectasid@otenet.gr; Theofanis Economopoulos - economopoulosth@ath.forthnet.gr

* Corresponding author
\end{abstract}

Published: 28 February 2006

BMC Cancer2006, 6:46 doi:10.1 186/147I-2407-6-46
Received: 09 November 2005

Accepted: 28 February 2006

This article is available from: http://www.biomedcentral.com/147/-2407/6/46

(c) 2006Kountourakis et al; licensee BioMed Central Ltd.

This is an Open Access article distributed under the terms of the Creative Commons Attribution License (http://creativecommons.org/licenses/by/2.0), which permits unrestricted use, distribution, and reproduction in any medium, provided the original work is properly cited.

\begin{abstract}
Background: Colorectal cancer remains a major cause of cancer mortality in the Western world. A limited number of studies has been conducted in respect of Her-3 and Her-4 expression and their correlation with clinical parameters and prognosis in colorectal carcinomas. In this study we sought to determine the pattern and the prognostic significance of HER-3 and HER-4 in colorectal adenocarcinoma.
\end{abstract}

Methods: We studied HER-3 and HER-4 protein expression in 106 paraffin embedded specimens of primary colorectal tumors using immunohistochemistry. The pattern and protein expression levels of HER-3 and HER-4 were correlated with several clinical and pathological parameters.

Results: HER-3 staining displayed membranous and cytoplasmic expression pattern in 18 (17\%) and 30 samples (28,3\%), respectively. HER-4 membranous and cytoplasmic expression was found in $20(18,9 \%)$ and 32 samples $(30,2 \%)$, respectively. Specimens regarded as positive for HER-3 cytoplasmic expression were associated with moderate tumor grade $(p=0,032)$ and older median age $(p=0,010)$. Specimens regarded as positive for HER-4 membranous protein expression were associated with involved lymphnodes $(p=0,0003)$. Similar results were obtained when considering Her-3 and Her-4 protein expression irrespective of their cellular localization. There was no correlation between the expression of HER-3 and HER-4 and patients outcome.

Conclusion: HER-4 membranous protein expression was found to predict for lymph nodes positivity in this cohort of patients with colorectal cancer.HER-4 expression status may identify tumors with aggressive biological behavior and increased metastatic potential. 


\section{Background}

Colorectal cancer remains a major cause of cancer mortality in the Western world both in men and women. It is the second most common malignancy (13.1\%) and the second most common cause of cancer death in Europe[1]. The incidence of colorectal cancer has been increasing worldwide rapidly over the past decades.

The stage of the disease is the most important factor predicting the treatment's outcome[2]. At presentation, 30\% of the patients have locally advanced cancer or metastatic disease, which discourages surgical care. Even among patients who undergo curative resection, approximately a $50 \%$ dies within five years. The role of adjuvant chemotherapy is clear in Dukes' C, but is controversial for Dukes' B cancers[3]. Although TNM (tumor-nodes-metastasis) classification is useful for staging patients and selecting them for specific treatment, it is not sufficient, as many patients at the same stage may have various outcomes. Therefore, there is a great need to identify useful prognostic markers to guide treatment decisions and/or to develop more effective treatments.

The transmembrane receptors that have action as tyrosine kinases play an important role in the pathogenesis of cancer in solid organs[4]. The type I receptor tyrosine kinase family comprises four homologous members: erbB1 (EGFR or HER-1), erbB2 (HER-2/neu), erbB3 (HER-3) and erbB4 (HER-4)[5].

The phosphorylation of these receptors through ligand binding and homo- or hetero-dimerization activates a cascade of signaling pathways that include: 1)the stress activated protein kinase pathway, involving protein kinase $\mathrm{C}$ and Jak/Stat, 2) the ras-raf-mitogen activated protein kinase pathway (MAP Kinase), 3) the protein serine/threonine kinase Akt pathway. These routs regulate cellular growth, differentiation, proliferation, angiogenesis and apoptosis[6].

Ten genes have been identified to encode HER-ligands. Out of these, the neuregulins(or heregulins) bind to HER3 and HER-4 while betacellulin, epiregulin and heparinbinding EGF bind to HER-4[7].

HER-3 gene is located on chromosome $12 \mathrm{q} 13$ and encodes a $160 \mathrm{KDa}$ transmembrane glycoprotein, that has no functional kinase domain and requires the dimerization with another receptor to activate downstream signal transduction pathways[8]. It's found to be overexpressed in various organs including breast, lung, pancreas and stomach. HER-4 gene is located on chromosome 2q33.334 and encodes a $180 \mathrm{KDa}$ transmembrane glycoprotein[9]. HER-4 plays a crucial role in several important pathological processes - such as malignancy and heart disease - and in the development and differentiation of various tissues, especially cardiovascular, neural system and mammary glands[10].

There is limited data regarding the prognostic role of HER3 and HER-4 in human cancer and these prove to be controversial. Some reports associate their overexpression with short while others with longer survival, thus, extended studies are required to ascertain definitively their prognostic value [11-13]. A limited number of studies has been conducted in respect of Her-3 and Her-4 expression and their correlation with clinical parameters and prognosis in colorectal carcinomas. Little therefore is known about their role in the pathogenesis of colorectal cancer. This study was conducted in order to investigate the immunohistochemical expression of Her-3 and Her-4 in colorectal carcinoma, to clarify their role in the prognosis of these carcinomas and to investigate the possible correlation with various clinical and pathological parameters.

\section{Methods}

\section{Patients and tumor specimens}

One hundred and six (106) formalin fixed and paraffin embedded colorectal cancer specimens, diagnosed at the Pathology Department of Evangelismos Hospital in Athens from 1997 to 2003, were studied. These specimens were collected from patients treated at the Oncology Unit of the Second Department of Internal Medicine - Propaedeutic, University of Athens. The clinical information of these patients derives from the medical records of the Department. Among the 106 patients, 103 had undergone surgical resection of the tumor; the remaining 3 patient's diagnosis was established by colonoscopy and consecutive biopsy. The evaluation of the 3 patients' preoperative imaging revealed metastasis. Since no surgery was performed, no information about the tumor size and the status of lymph nodes was available. None of the 106 patients had received chemotherapy or radiation therapy prior to surgery or died in the peri- or post-operative time period (within 45 days after surgery). The patients were staged using the Astler Coller - modified Dukes system. There were 30 patients (28.3\%) with Dukes B, 51 patients (48.1\%) with Dukes C and 25 patients (23.6\%) with Dukes D. Dukes A patients were not included in the study since they received no further treatment. Postoperative chemotherapy with irinotecan, leucovorin and 5-fluorouracil (IFL) was administered to the whole group of patients. Although there is controversy concerning the role of adjuvant IFL chemotherapy in Dukes' B and Dukes' $\mathrm{C}$ cancers, the selected treatment was part of an adjuvant protocol or as first line treatment for metastatic disease of the Hellenic Cooperative Oncology Group (HECOG). Informed consent was obtained from all the patients and the protocol was approved by Attikon university hospital 


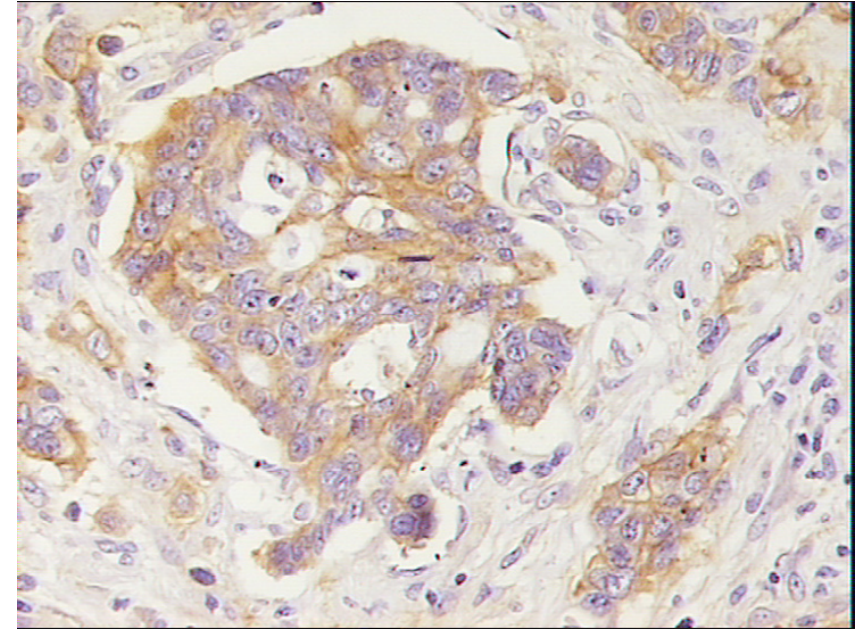

\section{Figure I}

HER-3 strong membranous and weak to moderate cytoplasmic staining $(\times 200)$.

ethics commitee. All patients received regular follow-ups and survival data as of March 2005 were ascertained through the patients' records. The median duration of the follow-ups was 31 months (range 7-125 months).

\section{Immunohistochemistry}

All the available hematoxylin and eosin stained slides of surgical specimens were reviewed and representative paraffin blocks for each case were selected for immunohistochemical study. Two serial sections of $4 \mu \mathrm{m}$ thick were cut from each block and placed onto Super Frost Plus glassslides. Following deparaffinization in xylene, the slides were rehydrated and washed in Tris Buffered Saline (TBS). The endogenous peroxidase activity was quenched by 10 min incubation in a mixture of $3 \%$ hydrogen peroxide solution in $100 \%$ methanol (Sigma). Slides were cleared with TBS and placed at room temperature for 1 hour. They were then incubated with monoclonal mouse antibody to human Her-3 protein (MAb-MsS-725-P, Neomarkers, Fremont, CA) at $1 / 35$ dilution and with monoclonal mouse antibody to human Her-4 protein (Ab-4, HFR-1, Neomarkers, Fremont, CA) at $1 / 100$ dilution overnight at $+4^{\circ} \mathrm{C}$. Slides were washed three times in TBS. The signal was visualized using the DAKO-EnVision Kit (k 5007 HRP Rabbit/Mouse $\mathrm{DAB}+$ ) for $60 \mathrm{~min}$. After washing with TBS, slides were kept in diaminobenzidine tetrahydrochloride for $7 \mathrm{~min}$ then counterstained with Mayers hematoxylin. Sections of breast carcinoma and striated muscle were used as positive controls. Slides were treated as negative controls by omitting the primary antibody.

\section{Scoring system}

Sections were examined using light microscopy by two independent observers (K.P. and D.R) who were unaware of the clinicopathological data. Interobserver variation was resolved by simultaneous dual re-evaluation. Both membranous and cytoplasmic immunostaining was evaluated semiquantitatively.

Membranous staining was considered positive $(+)$ when more than $1 \%$ of tumor cells were stained, irrespective of whether the staining pattern was complete circumferential or not (Fig. 1). When less than 1\% of tumor cells were stained it was considered negative (-).Cytoplasmic staining was scored as 0 , no staining or weak staining in $<10 \%$ of tumor cells; $1+$, weak immunostaining in $>10 \%$ of tumor cells; $2+$, moderate immunostaining in $>10 \%$ of tumor cells and $3+$, strong immunostaining in $>10 \%$ of tumor cells. Staining pattern was either granular or diffuse (Fig. 2). Scores of 0 and $1+$ indicate a negative tumor, while scores of $2+$ and $3+$ were regarded as positive.

Tumors were considered positive for both, membranous and cytoplasmic staining by using the above mentioned criteria, irrespective of whether the expression of the antibodies was localized in the same cell or in different groups of tumor cells (Fig. 3).

\section{Statistical analysis}

Categorical characteristics were summarized as percentages and their association with HER-3 and HER-4 overexpression was assessed using the Pearson $\chi^{2}$ test or the Fisher exact test[14]. Continuous characteristics comparisons were performed using the Mann- Whitney test. The probability of survival was calculated by the Kaplan-

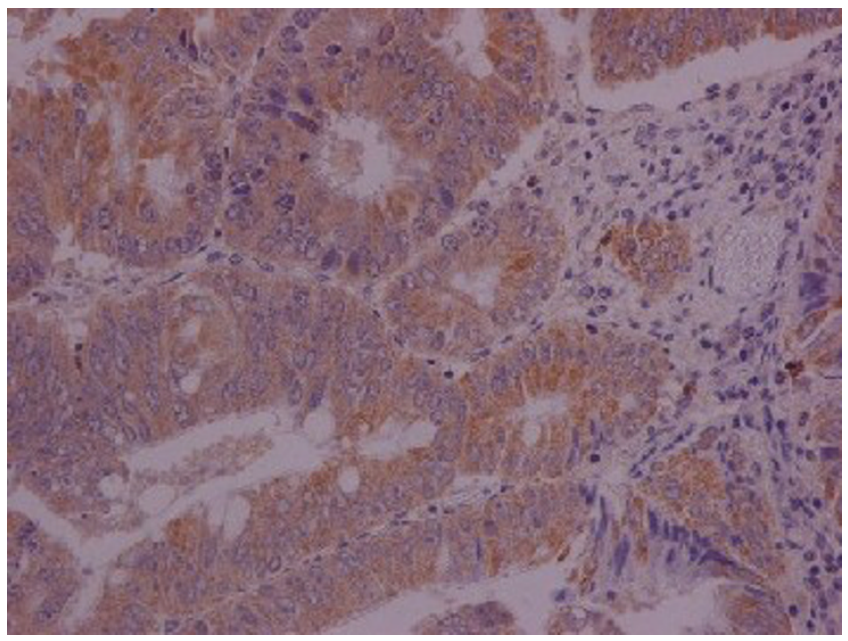

Figure 2

Positive diffused and granular exclusively cytoplasmic staining for HER-4 (x400) 


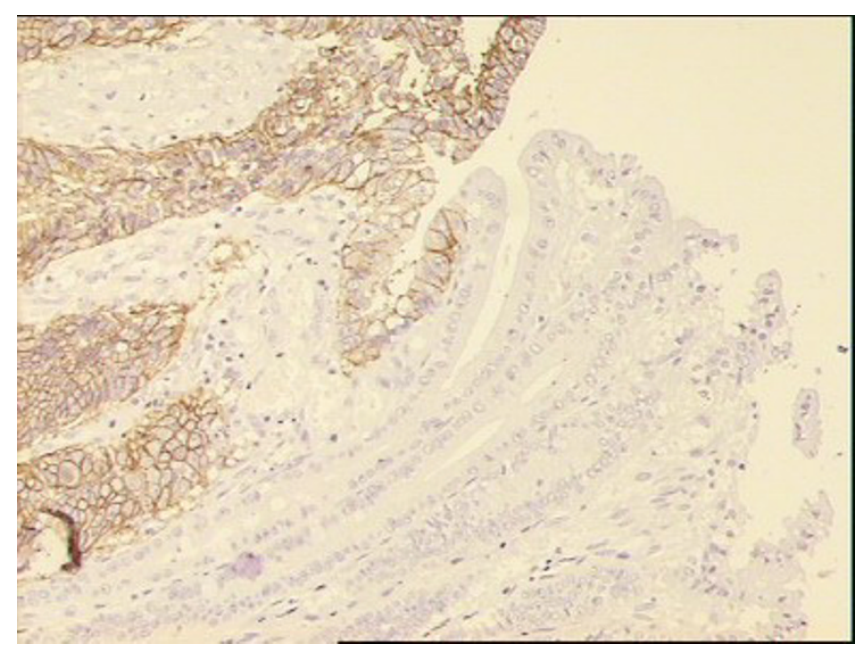

\section{Figure 3}

Complete circumferential membranous staining of HER-3 as opposed to the absence of immunoreaction in the adenomatous part of lesion $(\times 200)$

Meier method and differences in survival were assessed by the log- rank test[15]. All statistical tests were performed on $\mathrm{a}=0.05$ level of significance. Analysis was performed using SPSS 11.0.1 for windows.

\section{Results}

One hundred and six (106) colon carcinomas samples were examined. Sixty six patients were males $(62.3 \%)$ and forty patients were females $(37.7 \%)$. The median age of the patients was 63 years (35- 79 years). Patients' median follow up time was 31 months (7-125 months). In this period of time, 33 deaths and 38 relapses were observed. The 3 -year survival rate was $72.4 \%$, and the 5 -year survival rate was $45.7 \%$.

Eighteen samples (17\%) out of one hundred and six were evaluated as positive for HER-3 membranous protein expression. Cytoplasmic staining for HER-3 was evaluated as follows: 39 specimens $(36,8 \%)$ were negative for HER3 expression,37 $(34,9 \%)$ were scored as $1+, 20(18,9 \%)$ were scored as $2+$, while $10(9,4 \%)$ were scored as $3+$. Scores of $2+$ and $3+$ were regarded as positive expression.

Twenty samples $(18,9 \%)$ were positive for HER-4 membranous protein expression. Cytoplasmic staining for HER-4 was evaluated as follows:32 samples $(30,2 \%)$ were negative for HER-4 expression, $42(39,6 \%)$ were scored as $1+, 29(27,4 \%)$ were scored as $2+$, while $3(2,8 \%)$ were scored as $3+$. Scores of $2+$ and $3+$ were regarded as positive expression.

When considering Her-3 and Her-4 protein expression as positive irrespective of the cellular localization, 37 speci- mens $(34.9 \%)$ were found to be positive for Her-3 and 40 specimens (37.7\%) positive for Her-4.

Statistical analysis revealed no relationship between membranous Her-3 protein expression and any of the clinicopathological parameters under evaluation (Table 1). Patients regarded as negative for HER-3 cytoplasmic expression had smaller median age than those with positive HER-3 cytoplasmic expression (61 versus 66 years, $p$ $=0,010)$. All the patients regarded as positive for HER-3 cytoplasmic expression, had moderately differentiated tumors $(\mathrm{p}=0,032)$ (Table 1$)$.

The majority of positive samples for HER-4 membranous protein expression (95\%) were associated with involved lymph nodes $(\mathrm{p}=0,0003)$. Patients regarded as negative for HER-4 membranous expression were associated with Dukes' stage B $(\mathrm{p}=0.010)$ (Table 2). There was no association between HER-4 cytoplasmic protein expression and any clinicopathological parameter (Table 2).

For tumors that were considered as positive irrespective of the cellular localization of each marker, statistical analysis revealed that Her-3 expression was associated with an older median age group $(\mathrm{p}=0.009)$ and with moderately and poorly differentiated tumors $(\mathrm{p}=0.008$ and $\mathrm{p}=0.048$ respectively). Her-4 positivity was related with involved lymphnodes $(\mathrm{p}=0.010)$ (Table 3$)$. There was no association with patients' survival as analysed by Kaplan Meier's curves (data non shown).

Membranous or cytoplasmic expression of HER-3 and HER-4 was not associated with patients' survival as analysed by Kaplan Meier's curves (Figures 4, 5, 6, 7). Coexpression for HER -3 and HER- 4 was observed in 3 out of 106 cases $(2,8 \%)$ with membranous staining $(\mathrm{k}=0.025$, $\mathrm{p}=0,793)$ and in 15 out of 106 cases $(14,2 \%)$ with cytoplasmic staining $(\mathrm{k}=0.271, \mathrm{p}=0,005)$. There was no statistically significant difference in patients characteristics or overall survival with respect to Her-3 and Her-4 coexpression as compared to the expression of each antibody alone.

\section{Discussion}

Colorectal malignancies remain one of the major causes of cancer death. The last decade newer cytotoxic agents such as oxaliplatin and irinotecan have shown promise in the adjuvant setting. The administration of these agents has increased the overall survival rate as well as the time to progression in patients with metastatic cancer $[16,17]$. Despite significant improvements in traditional chemotherapy regimens, over the last years, the main efforts of research have focused on the use of targeted therapy. 
Table I: Patient clinicopathological data and HER-3 membranous and cytoplasmic expression

\begin{tabular}{|c|c|c|c|c|c|c|}
\hline \multirow[b]{2}{*}{ Characteristic } & \multicolumn{3}{|c|}{ HER-3 membranous expression } & \multicolumn{3}{|c|}{ HER-3 cytoplasmic expression } \\
\hline & $(+)(n=18)$ & $(-)(n=88)$ & $\mathrm{P}$ & $(+)(n=30)$ & $(-)(n=76)$ & $P$ \\
\hline Age Median (range) & $68(53-75)$ & $63(35-79)$ & 0.069 & $66(52-76)$ & $61(35-79)$ & 0.010 \\
\hline \multicolumn{7}{|l|}{ Sex } \\
\hline Male & $10(55.6 \%)$ & $56(63.6 \%)$ & 0.519 & $15(50.0 \%)$ & $51(67.1 \%)$ & 0.112 \\
\hline Female & $8(44.4 \%)$ & $32(36.4 \%)$ & & $15(50.0 \%)$ & $25(32.9 \%)$ & \\
\hline Size & $5(2-12)$ & $5(1.5-12)$ & 0.959 & $5(2-10)$ & $5(1.5-12)$ & 0.525 \\
\hline \multicolumn{7}{|l|}{ Lymph nodes status } \\
\hline$(+)$ & $13(72.2 \%)$ & $56(65.9 \%)$ & 0.603 & $20(66.7 \%)$ & $49(67.1 \%)$ & 0.964 \\
\hline$(-)$ & $5(27.8 \%)$ & $29(34.1 \%)$ & & $10(33.3 \%)$ & $24(32.9 \%)$ & \\
\hline \multicolumn{7}{|l|}{ Grade } \\
\hline Well & - & $3(3.4 \%)$ & 0.999 & - & $3(3.9 \%)$ & 0.556 \\
\hline Moderate & $18(100 \%)$ & $77(87.5 \%)$ & 0.205 & $30(100.0 \%)$ & $65(85.5 \%)$ & 0.032 \\
\hline Poor & - & $8(18 \%)$ & 0.346 & - & 8 (10.5\%) & 0.101 \\
\hline \multicolumn{7}{|l|}{ Dukes' stage } \\
\hline$B$ & $4(22.2 \%)$ & $26(29.5 \%)$ & 0.530 & $9(30.0 \%)$ & $21(27.6 \%)$ & 0.807 \\
\hline $\mathrm{C}$ & $11(61.1 \%)$ & $40(45.5 \%)$ & 0.226 & $14(46.7 \%)$ & 37 (48.7\%) & 0.851 \\
\hline $\mathrm{D}$ & $3(16.7 \%)$ & $22(25.0 \%)$ & 0.448 & 7 (23.3\%) & 18 (23.7\%) & 0.969 \\
\hline \multicolumn{7}{|l|}{ Site } \\
\hline Proximal colon & $4(22.2 \%)$ & $25(28.4 \%)$ & 0.774 & 7 (23.3\%) & 22 (28.9\%) & 0.534 \\
\hline Distal colon & 9 (50.0\%) & $28(31.8 \%)$ & 0.140 & $10(33.3 \%)$ & 27 (35.5\%) & 0.796 \\
\hline Rectum & $5(27.8 \%)$ & $35(39.8 \%)$ & 0.339 & $13(43.3 \%)$ & 27 (35.5\%) & 0.406 \\
\hline
\end{tabular}

The low molecular weight tyrosine kinase inhibitors and the monoclonal antibodies against EGFR are in clinical development $[18,19]$. These strategies have shown promise; more efforts focus on the identification of new molec- ular prognostic markers and the development of molecular targeted therapies against colorectal cancer.

The type I tyrosine kinase receptors and the associated signal transduction pathways have a crucial role in cancer

Table 2: Patient clinicopathological data and HER-4 membranous and cytoplasmic expression

\begin{tabular}{|c|c|c|c|c|c|c|}
\hline \multirow[b]{2}{*}{ Characteristic } & \multicolumn{3}{|c|}{ HER-4 membranous expression } & \multicolumn{3}{|c|}{ HER-4 cytoplasmic expression } \\
\hline & $(+)(n=20)$ & $(-)(n=86)$ & $\mathrm{P}$ & $(+)(n=32)$ & $(-)(n=74)$ & $P$ \\
\hline Age Median (range) & $64(40-75)$ & $63(35-79)$ & 0.906 & $64(40-76)$ & $63(35-79)$ & 0.656 \\
\hline \multicolumn{7}{|l|}{ Sex } \\
\hline Male & $13(65.0 \%)$ & $53(61.6 \%)$ & 0.779 & $20(62.5 \%)$ & $46(62.2 \%)$ & 0.974 \\
\hline Female & $7(35.0 \%)$ & $33(38.4 \%)$ & & $12(37.5 \%)$ & $28(37.8 \%)$ & \\
\hline Size & $5(1.6-8.5)$ & $5(1.5-12)$ & 0.383 & $5(2-10)$ & $5(1.5-12)$ & 0.128 \\
\hline \multicolumn{7}{|l|}{ Lymph nodes status } \\
\hline$(+)$ & $19(26.8 \%)$ & $50(60.2 \%)$ & 0.003 & $25(78.1 \%)$ & $44(62.0 \%)$ & 0.107 \\
\hline$(-)$ & I (5.0\%) & $33(39.8 \%)$ & & 7 (21.9\%) & 27 (38.0\%) & \\
\hline \multicolumn{7}{|l|}{ Grade } \\
\hline Well & - & $3(3.5 \%)$ & 0.999 & - & $3(4.1 \%)$ & 0.552 \\
\hline Moderate & $17(85.0 \%)$ & $78(90.7 \%)$ & 0.431 & $31(96.9 \%)$ & 64 (86.5\%) & 0.167 \\
\hline Poor & $3(15.0 \%)$ & $5(5.8 \%)$ & 0.171 & I (3.1\%) & 7 (9.5\%) & 0.430 \\
\hline \multicolumn{7}{|l|}{ Dukes' stage } \\
\hline B & I (5.0\%) & 29 (33.7\%) & 0.010 & 7 (21.9\%) & 23 (31.1\%) & 0.334 \\
\hline C & II (55.0\%) & 40 (46.5\%) & 0.494 & $14(43.8 \%)$ & 37 (50.0\%) & 0.554 \\
\hline $\mathrm{D}$ & $8(40.0 \%)$ & $17(19.8 \%)$ & 0.078 & II (44.4\%) & $14(18.9 \%)$ & 0.085 \\
\hline \multicolumn{7}{|l|}{ Site } \\
\hline Proximal colon & $4(20.0 \%)$ & $25(29.1 \%)$ & 0.412 & II (34.4\%) & I 8 (24.3\%) & 0.287 \\
\hline Distal colon & $9(45.0 \%)$ & 28 (75.7\%) & 0.293 & II (34.4\%) & $26(35.1 \%)$ & 0.940 \\
\hline Rectum & 7 (6I.6\%) & $33(38.4 \%)$ & 0.779 & $10(31.2 \%)$ & 30 (40.5\%) & 0.365 \\
\hline
\end{tabular}


Table 3: Patient clinicopathological data and HER-3, HER-4 expression

\begin{tabular}{|c|c|c|c|c|c|c|}
\hline \multirow[b]{2}{*}{ Characteristic } & \multicolumn{3}{|c|}{ HER- 3 expression (membranous or cytoplasmic) } & \multicolumn{3}{|c|}{ HER- 4 expression (membranous or cytoplasmic) } \\
\hline & $(+)(n=37)$ & $(-)(n=69)$ & $\mathrm{P}$ & $(+)(n=40)$ & $(-)(n=66)$ & $P$ \\
\hline $\begin{array}{l}\text { Age Median } \\
\text { (range) }\end{array}$ & $65(52-76)$ & $61(35-79)$ & 0.009 & $64.5(40-76)$ & $61(35-79)$ & 0.189 \\
\hline \multicolumn{7}{|l|}{ Sex } \\
\hline Male & $19(51.4 \%)$ & 47 (68.1\%) & 0.098 & $24(60 \%)$ & $42(63.6 \%)$ & 0.836 \\
\hline Female & $18(48.6 \%)$ & $22(31.9 \%)$ & & $16(40 \%)$ & $24(36.4 \%)$ & \\
\hline Size & $5(2-12)$ & $5(1.5-12)$ & 0.425 & $5(2-12)$ & $5(1.5-12)$ & 0.195 \\
\hline \multicolumn{7}{|c|}{ Lymph nodes status } \\
\hline$(+)$ & $25(67.6 \%)$ & $44(63.8 \%)$ & 0.999 & $33(82.5 \%)$ & $36(54.5 \%)$ & 0.010 \\
\hline$(-)$ & $12(32.4 \%)$ & $22(31.9 \%)$ & & 7 (I7.5\%) & $27(40.9 \%)$ & \\
\hline \multicolumn{7}{|l|}{ Grade } \\
\hline Well & - & $3(4.2 \%)$ & 0.550 & - & $3(4.5 \%)$ & 0.288 \\
\hline Moderate & 37 (100\%) & $58(84.1 \%)$ & 0.008 & 37 (92.5\%) & $58(87.9 \%)$ & 0.529 \\
\hline Poor & - & $8(11.6 \%)$ & 0.048 & $3(7.5 \%)$ & $5(7.6 \%)$ & 0.999 \\
\hline \multicolumn{7}{|l|}{ Dukes' stage } \\
\hline B & II (29.7\%) & 19 (27.5\%) & 0.824 & 7 (I7.5\%) & $23(34.8 \%)$ & 0.075 \\
\hline C & 18 (48.6\%) & 33 (47.8\%) & 0.999 & $20(50 \%)$ & $31(47 \%)$ & 0.842 \\
\hline$D$ & $8(21.6 \%)$ & $17(24.6 \%)$ & 0.813 & $13(32.5 \%)$ & $12(18.2 \%)$ & 0.104 \\
\hline \multicolumn{7}{|l|}{ Site } \\
\hline Proximal colon & $10(27 \%)$ & 19 (27.5\%) & 0.999 & $12(30 \%)$ & 17 (25.8\%) & 0.658 \\
\hline Distal colon & $13(35.1 \%)$ & $24(34.8 \%)$ & 0.999 & $14(35 \%)$ & $23(34.8 \%)$ & 0.999 \\
\hline Rectum & 14 (37.8\%) & 26 (37.7\%) & 0.999 & $26(39.4 \%)$ & $14(35 \%)$ & 0.684 \\
\hline
\end{tabular}

Proximal colon:cecum, ascending, transverse colon. Distal colon:descending, sigmoid colon

biology and are attractive targets for cancer therapy. Out of the four members of the type I receptor tyrosine kinase family, EGFR and Her-2 have been widely studied on several human tumors, mostly breast and colon carcinoma. In most studies their protein expression as evaluated by

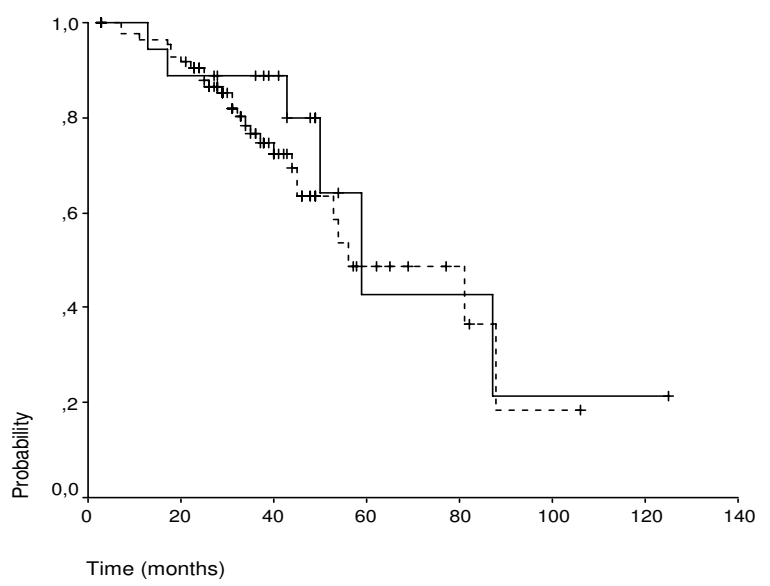

\section{Figure 4}

Kaplan Meier curves for the overall survival of patients with positive (continuous line) and negative (dotted line) HER-3 membranous expression. immunohistochemical techniques was found to be related to poor prognostic factors[20,21]. On the contrary the role of Her- 3 and Her- 4 in the pathobiology of carcinomas has not yet been clarified. Most of the studies were conducted on breast carcinomas and the results have

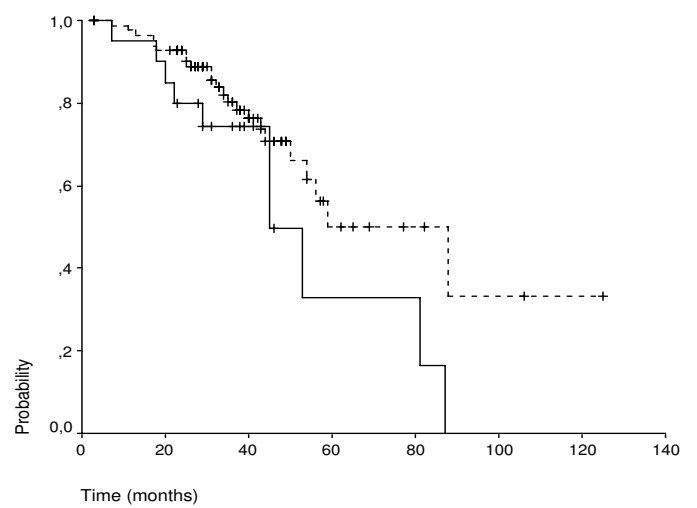

Figure 5

Kaplan Meier curves for the overall survival of patients with positive (continuous line) and negative (dotted line) HER-4 membranous expression. 


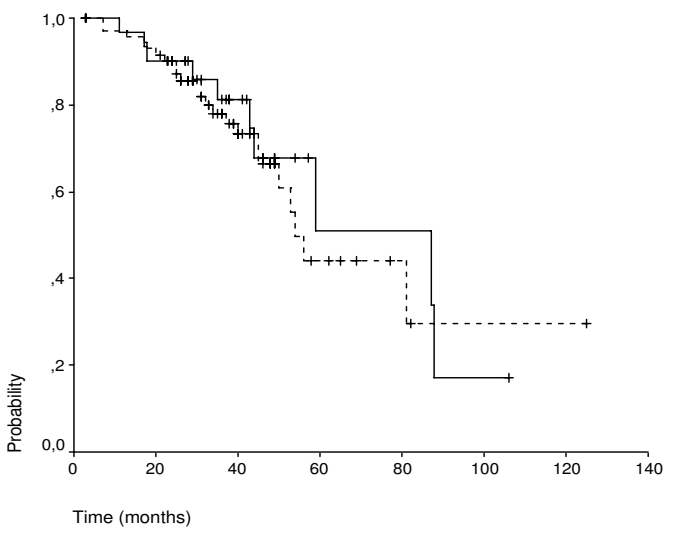

Figure 6

Kaplan Meier curves for the overall survival of patients with positive (continuous line) and negative (dotted line) HER-3 cytoplasmic expression.

proven to be controversial. Most investigators revealed that HER-3 protein expression on breast carcinomas was associated with poor prognostic factors such as large tumor size, high grade of malignancy and lymph node metastasis[22,23]. However, others have found that HER3 expression was associated with an improved 10- year survival as well as estrogen receptor (ER) positivity, which is a favorable prognostic factor for breast cancer[24]. HER4 protein overexpression on breast carcinomas was associated in several studies with the longer survival of patients, ER positivity, low proliferation rate and low probability of recurrence, while other studies have correlated HER-4 overexpression with negative prognostic factors [25-27]. Results in human breast cancer cell lines are also conflicting $(28,29)$.

In colorectal cancer, only a few studies have investigated the protein expression of Her-3 and Her-4. From the obtained data, the incidence of HER-3 expression in colorectal cancer ranges from $36 \%$ to $89 \%(30,31)$. Poller et al. (32) revealed a 88,8\% positive rate for HER-3 expression, both mebranous and cytoplasmic. Rajkumar et al. (33) detected a 68,75\% rate for HER-3 expression, predominantly cytoplasmic. Maurer and co-workers (31) demonstrated that HER-3 is expressed in $89 \%$ in primary colorectal carcinomas and the immunoreactivity was both membranous and cytoplasmic. Kapitanovic et al.(34) revealed a $78 \%$ rate for HER-3 expression, which was exclusively cytoplasmic. Lee et al.(30) detected a $36 \%$ rate for membranous HER-3 expression and a $22 \%$ rate for

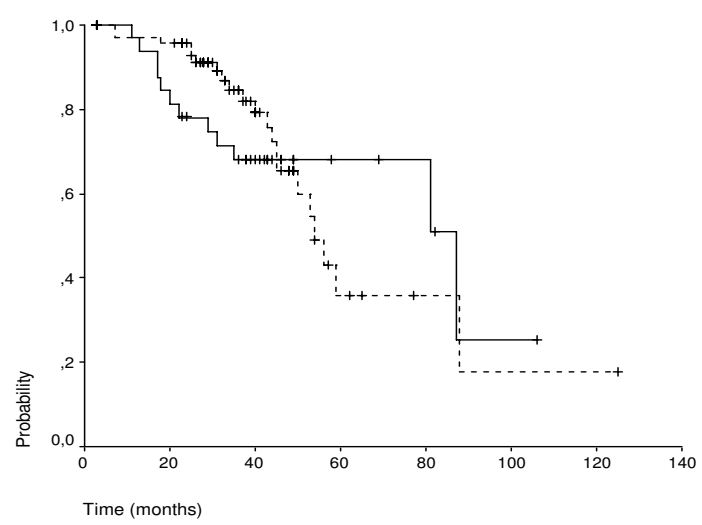

Figure 7

Kaplan Meier curves for the overall survival of patients with positive (continuous line) and negative (dotted line) HER-4 cytoplasmic expression.

membranous HER-4 expression. To the best of our knowledge this was the only study conducted on Her-4 protein expression in colon carcinoma

In our study, both membranous and cytoplasmic Her-3 and Her-4 protein expression was identified. The rates of expression for Her-3 and Her- 4 respectively were as follows: $17 \%$ membranous, $28.3 \%$ cytoplasmic and $18.9 \%$ membranous, $30.2 \%$ cytoplasmic. Both membranous and cytoplasmic staining was found in $11.3 \%$ of Her-3 and $14.1 \%$ of Her- 4 positive cases. As opposed to the five studies already mentioned, we evaluated protein expression not only irrespective of the cellular localization of the antibody but also on different cellular compartment (membrane or cytoplasm) separately, assuming that this phenomenon might be related to divergent functional properties of the genes.

In their study, Maurer et al.(31) suggested a growthenhancing role of Her-3 in colorectal cancer. They speculated that extreme Her-3 immunostaining was associated with tumors presenting mucus production, which is a sign of advanced tumor disease. Overexpression of Her-3 was also found in the invading edge of the tumor as well as in the transition zone between adenomatous and cancerous tissue (Fig. 3). These findings were considered to indicate the role of Her-3 in tumor progression. Moreover, Kapitanovic et al.(34) revealed that patients regarded as negative for HER-3 expression survived significantly longer than patients with HER-3 expression $(\mathrm{p}<0.05)$. On the 
other hand, the results of Lee et al.(30) demonstrated that HER-3 overexpression was correlated with patients in the early stages of the disease $(\mathrm{p}<0.0001)$. In our study, Her3 membranous expression was not related to any of the clinicopathological parameters under evaluation while positive cytoplasmic Her-3 protein expression was found mostly in moderately differentiated tumors $(\mathrm{p}=0.032)$ and in the older age group ( $\mathrm{p}=0.010)$. When cases with both membranous and cytoplasmic staining were considered as positive, then also poorly differentiated tumors ( $\mathrm{p}$ $=0.048$ ) were found to have a statistical significant overexpression of Her-3 protein. Due to the small number of cases ( 3 highly differentiated -8 poorly differentiated) these findings are not sufficient to support any possible role of Her-3 in tumor progression.

Regarding Her-4 protein expression on colorectal cancer, only Lee et al have recently conducted a detailed study. In their series, $22 \%$ of the cases showed membranous overexpression of Her-4. This incidence tended to be higher in later stage than in early stage cancers. This is in accordance with our observations. In our study, the majority of positive samples for HER-4 membranous protein expression (95\%) were associated with involved lymph nodes $(\mathrm{p}=$ $0,0003)$. The same results were obtained when cases with both membranous and cytoplasmic expression of Her-4 were considered as positive $(\mathrm{p}=0.010)$. Patients who tested negative for HER-4 membranous expression were associated with Dukes' stage B cancer $(p=0.010)$.

The coexpression of both Her-3 and Her- 4 membranous and cytoplasmic immunostaining for each marker separately was not found to be related to any clinicopathological parameter.

\section{Conclusion}

Our findings do not support any major role between Her3 protein expression and tumor biology in colon carcinoma. Judging from the two existing studies on Her-4, the study of Lee et. al (30) and our own, there is strong evidence that Her-4 membranous protein expression in colon carcinoma, might indicate at tumors with more aggressive biological behavior. If this proves to be right, then some patients could be favored from the administration of pan-Her inhibitors. Certainly, our relatively small sample may not have been enough to detect differences. Larger studies with extended follow-ups will be required to ascertain the prognostic value of Her-3 and Her-4 expression in colorectal carcinomas. Moreover, in this study, only HER-3, HER-4 part of the signaling system was evaluated. Estimating the expression of all four members of the Her family as well as of an array of receptor-specific ligands would probably give more information on some steps of the signal transduction pathway and on the clini- cal significance of the interactions between the different receptors.

\section{Competing interests}

The author(s) declare that they have no competing interests.

\section{Authors' contributions}

P.K. participated in study design, collected specimens and clinical data, interpreted the data, carried out functional studies, drafted the manuscript.

K.P. participated in study design, carried out the functional studies, evaluated immunohistochemistry, interpreted the data

\section{A.P. participated in manuscript preparation.}

D.R. provided the specimens, evaluated immunohistochemistry.

N.X. provided clinical data.

E.P. revised the manuscript.

D.P. supervised and controlled the whole study.

T.E. supervised and controlled the whole study.

All Authors read and approved the final manuscript.

\section{Acknowledgements}

We thank Miss G. Vourli for the statistical analysis and Mr. G. Economou for his technical assistance.

\section{References}

I. Boyle P, Ferlay J: Cancer incidence and mortality in Europe. Ann Oncol 2005, 16:48I-488.

2. Chamberlain NL, Ward RL, Hawkins NJ: Clinicopathological significance of CERB-B2 expression in colorectal carcinoma. Oncol rep 1999, 6:527-53।.

3. Coombs LM, Oliver S, Sweeney E, Knowles M: Immunocytochemical localization of c-erbB2 protein in transitional cell carcinoma of the urinary bladder. J Pathol 1993, I69(I):35-42.

4. Corbett IP, Henry JA, Angus B, Watchom CJ, Wilkinson C, Hennessy C, Gullick WJ, Tuzi NL, May FE, Westley BR: NCL-BII, a new monoclonal antibody regognising the internal domain of the C-ERBB2 oncogene protein effective for use on formalinfixed paraffin embedded tissue. J Pathol 1990, 161:15-25.

5. De Potter CR, Quatacker J, Maertens G, Van Daeles, Pauwels C, Verhofstede $\mathrm{C}$, Eechaute $\mathrm{W}$, Roels $\mathrm{H}$ : The subcellular localization of the neu protein in human normal and neoplastic cells. Int J Cancer 1989, 44:869-974.

6. Essapen S, Thomas H, Green M, De Veries C, Cook MG, Marks C, Topham C, Modjtahedi $\mathrm{H}$ : The expression and prognostic significance of Her-2 in colorectal cancer and its relationship with clinicopathological parameters. Int J Oncol 2004, 24:24I-248.

7. Half E, Broaddus R, Danenberg KD, Danenberg PV, Ayers GD, Sinicrope FA: Her-2 receptor expression, localization and activation in colorectal cancer cell lines and human tumours. Int $J$ Cancer 2004, 108:540-548.

8. Jacobs TW, Gowm AM, Yaziji H, Barnes MJ, Schnitt SJ: Specificity of Hercep test in determing HER-2/neu status of breast cancers 
using the United States Food and Drug Administrationapproved scoring system. J Clin Oncol 1999, 17:1983-1987.

9. Kapitanovic S, Radosevic S, Kapitanovic M, Andelinovic S, Ferencic Z, Tavassoli M, Primorac D, Sonicki Z, Spaventi S, Pavelic K, Spaventi R: The expression of $\mathrm{p} \mid 85$ HER-2/neu correlates with the stage of disease and survival in colorectal cancer. Gatroenterology 1997, I I 2: I I03-I II3.

10. Kay EW, Walsh BC], Cassidy M, Curran B, Leader M: C-erbB2 immunostaining: problems wih interpretation. J Clin Pathol 1994, 47:816-822.

11. Kraus MH, Popescu NC, Amsbaugh SC, King CR: Overexpression of the EGF receptor -related proto-oncogene erbB-2 in human mammary tumor cell lines by different molecular mechanisms. EMBO J 1987, 6:605-10.

12. Lee JC, Wang ST, Chow NH, Yang HB: Investigation of the prognostic value of co-expressed ErBb family members for the survival of colorectal cancer patients after curative surgery. Eur Journal of Cancer 2002, 38: I065-I07I.

13. Menard S, Casalini M, Campiglio M, Pupa S: HER2 over-expression in various tumour types, focussing on its relationship to the development of invasive breast cancer. Ann Oncol 200I, I 2(suppI I):SI5-SI9.

14. Midgley RS, Kerr DJ: Adjuvant treatment of colorectal cancer. Cancer Treat Rev 1997, 23:135-52.

15. Midgley RS, Kerr DJ: Colorectal cancer. Lancet 1999, 353:391-9.

16. Nathanson DR, Culliford AT, Shia J, Chen B, D'Alessio M, Zeng ZS, Nash GM, Gerald W, Barany F, Paty BB: Her-2/neu expression and gene amplification in colon cancer. Int J Cancer 2003, 105:796-802.

17. Olayioye M, Neve RM, Lane HA, Hynes NE: The ERBB signaling network: receptor heterodimerization in development and cancer. Embo J 2000, 19:3159-3167.

18. Ooi A, Takehana T, Li X, Suzuki S, Kunitomo K, lino H, Fujii H, Takeda $Y$, Dobashi $Y$ : Protein overexpression and gene amplification of Her-2 and EGFR in colorectal cancers: An immunohistochemical and fluorescent in situ hybridization study. Modern Pathology 2004, 17:895-904.

19. Osako T, Miyahara M, Uchino S, Inomata M, Kitano S, Kobayashi M: Immunohistochemical study of C-ERBB2 protein in colorectal cancer and the correlation with patient survival. Oncology 1998, 55:548-555.

20. Porebska I, Harlozinska A, Bojarowski T: Expression of the tyrosine kinase activity growth factor receptors (EGFR, ERBB2, ERBB3) in colorectal adenocarcinomas and adenomas. Tumour Biol 2000, 2 I (2): 105-15.

21. Salomon D, Brandt R, Ciardiello F, Normanno N: Epidermal growth factor-related peptides and their receptors in human malignancies. Crit rev Oncol Hematol 1995, 19: 183-232.

22. Slamon DJ, Clark GM, Wong SG, Levin WJ, Ullrich A, McGuire WL: Human breast cancer: correlation of relapse and survival with amplification of the HER-2/neu oncogene. Science 1987, 235: $177-82$.

23. Slamon DJ, Leyland-Jones B, Shak S, Fuchs H, Paton V, Bajamonde A, Fleming T, Eiermann W, Wolter J, Pegram M, Baselga J, Norton L: Use of chemotherapy plus a monoclonal antibody against HER 2 for metastatic breast cancer that overexpresses HER 2. N Engl J Med 200I, 344:783-92.

24. Slikowski MX, Du Bois NR: Her-2/neu overexpression in colonic malignancies. Gastroenterology 2002, I 22(I):248-249.

25. Van der Burg ME, Henzen-Logmans SC, Foekens JA, Berns EM, Rodenburg C], Van Putten WL, Klijn JC: The prognostic value of epidermal growth factor receptors, determined by both immunohistochemistry and ligand assays, in primary epithelian ovarian cancer: a pilot study. Eur J Cancer 1993, 29A:195I-1957.

26. Vogel CL, Cobleigh MA, Tripathy D, Gutheil JC, Harris LN, Fehrenbacher L, Slamon DJ, Murphy M, Novotny WF, Burchmore M, Shak S, Stewart SJ, Press M: Efficacy and safety of trastuzumab as a single agent in first -line treatment of HER-2 overexpressing metastatic breast cancer. / Clin Oncol 2002, 20:719-26.

27. Yarden Y: The EGFR family and its ligands in human cancer: signalling mechanisms and therapeutic opportunities. Eur J Cancer 200I, 37:S3-S8.

\section{Pre-publication history}

The pre-publication history for this paper can be accessed here:

http://www.biomedcentral.com/1471-2407/6/46/prepub
Publish with Bio Med Central and every scientist can read your work free of charge

"BioMed Central will be the most significant development for disseminating the results of biomedical research in our lifetime. "

Sir Paul Nurse, Cancer Research UK

Your research papers will be:

- available free of charge to the entire biomedical community

- peer reviewed and published immediately upon acceptance

- cited in PubMed and archived on PubMed Central

- yours - you keep the copyright

Submit your manuscript here:

http://www.biomedcentral.com/info/publishing_adv.asp
BiolMedcentral 